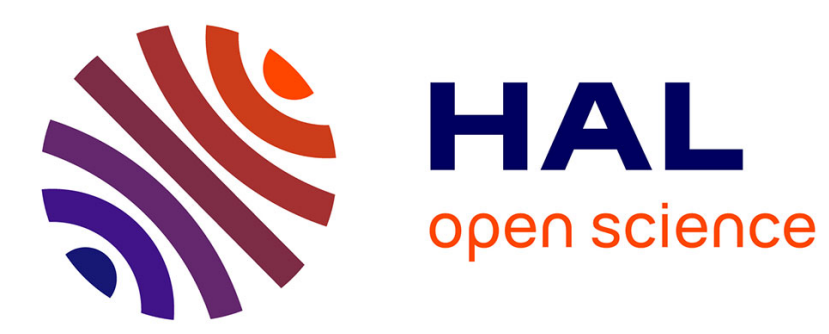

\title{
2,5-Thiophenedicarboxylate: An interpenetration-inducing ligand in uranyl chemistry
}

Pierre Thuéry, Jack Harrowfield

\section{To cite this version:}

Pierre Thuéry, Jack Harrowfield. 2,5-Thiophenedicarboxylate: An interpenetration-inducing ligand in uranyl chemistry. Inorganic Chemistry, In press, 60 (12), pp.9074-9083. 10.1021/acs.inorgchem.1c01069 . cea-03258420

\section{HAL Id: cea-03258420 https://hal-cea.archives-ouvertes.fr/cea-03258420}

Submitted on 11 Jun 2021

HAL is a multi-disciplinary open access archive for the deposit and dissemination of scientific research documents, whether they are published or not. The documents may come from teaching and research institutions in France or abroad, or from public or private research centers.
L'archive ouverte pluridisciplinaire HAL, est destinée au dépôt et à la diffusion de documents scientifiques de niveau recherche, publiés ou non, émanant des établissements d'enseignement et de recherche français ou étrangers, des laboratoires publics ou privés. 


\title{
2,5-Thiophenedicarboxylate: an Interpenetration-Inducing Ligand in Uranyl Chemistry
}

\author{
Pierre Thuéry*,† and Jack Harrowfield*,\$ \\ †Université Paris-Saclay, CEA, CNRS, NIMBE, 91191 Gif-sur-Yvette, France \\ *Université de Strasbourg, ISIS, 8 allée Gaspard Monge, 67083 Strasbourg, France
}

\begin{abstract}
Seven uranyl ion complexes have been crystallized under solvo-hydrothermal conditions from 2,5thiophenedicarboxylic acid $\left(\mathrm{tdcH}_{2}\right)$ and diverse additional, structure-directing species. $\left[\mathrm{UO}_{2}(\mathrm{tdc})(\mathrm{DMF})\right](\mathbf{1})$ is a 2-stranded monoperiodic coordination polymer, while $\left[\mathrm{PPh}_{3} \mathrm{Me}\right]\left[\mathrm{UO}_{2}(\mathrm{tdc})(\mathrm{HCOO})\right](2)$ is a simple chain with terminal formate coligands. Although it is also monoperiodic, $\left[\mathrm{C}\left(\mathrm{NH}_{2}\right)_{3}\right]\left[\mathrm{H}_{2} \mathrm{NMe}_{2}\right]_{2}\left[\left(\mathrm{UO}_{2}\right)_{3}(\mathrm{tdc})_{4}(\mathrm{HCOO})\right](3)$ displays an alternation of tetra- and hexanuclear rings. 2-Stranded subunits are bridged by oxo-coordinated $\mathrm{Ni}^{\mathrm{II}}$ cations to form a diperiodic network in $\left[\mathrm{UO}_{2}(\mathrm{tdc})_{2} \mathrm{Ni}(\right.$ cyclam) $]$ (4), but a homometallic sql diperiodic assembly is built in $\left[\mathrm{Cu}\left(R, S-\mathrm{Me}_{6}\right.\right.$ cyclam $\left.)\left(\mathrm{H}_{2} \mathrm{O}\right)\right]\left[\mathrm{UO}_{2}(\mathrm{tdc})_{2}\right] \cdot \mathrm{H}_{2} \mathrm{O}(5)$, to which the counterion is hydrogen bonded only. Diperiodic networks with the heb topology are formed in both $\left[\mathrm{Zn}(\mathrm{phen})_{3}\right]\left[\left(\mathrm{UO}_{2}\right)_{2}(\mathrm{tdc})_{3}\right] \cdot 2 \mathrm{H}_{2} \mathrm{O} \cdot 3 \mathrm{CH}_{3} \mathrm{CN}(\mathbf{6})$ and $\left[\mathrm{PPh}_{4}\right]_{2}\left[\left(\mathrm{UO}_{2}\right)_{2}(\mathrm{tdc})_{3}\right] \cdot 2 \mathrm{H}_{2} \mathrm{O}(7)$. The slightly undulating layers in $\mathbf{6}$ are crossed by oblique columns of weakly interacting counterions in polythreading-like fashion. In contrast, the larger curvature in 7 allows for 3-fold, parallel 2D interpenetration to occur. These results are compared with previously reported cases of interpenetration and polycatenation in the uranyl-tdc ${ }^{2-}$ system.
\end{abstract}




\section{INTRODUCTION}

The marked affinity of the dioxouranium(VI) (uranyl) cation for carboxylate-donor ligands has led to extensive investigations of its complex formation with such ligands, ${ }^{1-5}$ one of which that has been of broad interest as a divergent, ditopic species being the dianion of 2,5thiophenedicarboxylic acid $\left(\mathrm{tdcH}_{2}\right)$. While simple dinuclear uranyl ion complexes including terminal terpyridine or trispyridyltriazine molecules are known, ${ }^{6,7}$ this ligand has been found to give several mono- and diperiodic coordination polymers, ${ }^{8-11}$ some of the latter displaying interpenetration ${ }^{9,11}$ or polycatenation, ${ }^{10}$ and two triperiodic frameworks obtained in the presence of coordinated $\mathrm{N}$-methyl-2-pyrrolidone. ${ }^{12}$ The syntheses of most of these complexes exploited structure-directing effects provided by additional ligands, counterions or guest molecules. Considering the extent to which the structures involving $\operatorname{tdc}^{2-}$ are sensitive to such effects, it appeared worthwhile to further investigate the influence of different counterions or structure-directing species displaying varying characteristics in terms of bulkiness and possible weak interactions. In particular, the significant number of interpenetrated structures which have been found in this family was an incentive to further search for the structure-directing species able to promote this phenomenon, of which several examples have lately been given in uranyl chemistry $^{13-26}$ (an overview of the cases reported prior to 2017 has previously been given ${ }^{13}$ ). While interpenetration can be considered simply as a means whereby possible voids in a structure are eliminated, what is significant in known cases with uranyl-tdc ${ }^{2-}$ species is that interpenetration results in cavities which can be at least partly occupied by countercations. We have obtained seven new uranyl ion complexes with $\operatorname{tdc}^{2-}$ by using additional species different from those in the former reports, namely $N, N$-dimethylformamide (DMF) as a secondary ligand, the dimethylammonium, guanidinium and $\mathrm{PPh}_{3} \mathrm{Me}^{+}$or $\mathrm{PPh}_{4}^{+}$phosphonium cations as counterions, and the metal-containing species $[\mathrm{Ni}(\mathrm{cyclam})]^{2+},\left[\mathrm{Cu}\left(R, S-\mathrm{Me}_{6} \mathrm{cyclam}\right)\right]^{2+}$, and $\left[\mathrm{Zn}(\text { phen })_{3}\right]^{2+}$, which are either separate as counterions or part of the polymeric structure 
$($ cyclam $=1,4,8,11$-tetraazacyclotetradecane; $R, S$-Me 6 cyclam (meso isomer $)=7(R), 14(S)$ $5,5,7,12,12,14$-hexamethylcyclam; phen $=1,10$-phenanthroline). The choice of counterions was guided by several considerations. Guanidinium is particularly appealing for its high potential as a hydrogen bond donor, with six suitable hydrogen atoms, and it can thus be expected to behave as a structure-directing species. The bulky $\mathrm{PPh}_{3} \mathrm{Me}^{+}$or $\mathrm{PPh}_{4}^{+}$, and $\left[\mathrm{Zn}(\text { phen })_{3}\right]^{2+}$ cations may be involved in aromatic $\cdots$ aromatic and $\mathrm{CH}-\mathrm{O}$ interactions, but their large size is the primary source of their effect on the structure. Lastly, $[\mathrm{Ni}(\text { cyclam })]^{2+}$ and $\left[\mathrm{Cu}\left(R, S-\mathrm{Me}_{6} \text { cyclam }\right)\right]^{2+}$ associate bulkiness and hydrogen bonding capacity, and they additionally possess two axial coordination sites which allow their integration within the polymeric assembly through bonding to oxygen donors. The present complexes, which have been characterized by their crystal structure, are mono- or diperiodic coordination polymers, and one of them provides a new example of interpenetration in this family of complexes.

\section{EXPERIMENTAL SECTION}

Syntheses. Caution! Uranium is a radioactive and chemically toxic element, and uranium-containing samples must be handled with suitable care and protection. Small quantities of reagents and solvents were employed to minimize any potential hazards arising both from the presence of uranium and the use of pressurized vessels for the syntheses.

$\left[\mathrm{UO}_{2}\left(\mathrm{NO}_{3}\right)_{2}\left(\mathrm{H}_{2} \mathrm{O}\right)_{2}\right] \cdot 4 \mathrm{H}_{2} \mathrm{O}$ (RP Normapur, 99\%) was purchased from Prolabo. 2,5Thiophenedicarboxylic acid was from Aldrich. $\left[\mathrm{Ni}(\right.$ cyclam $\left.)\left(\mathrm{NO}_{3}\right)_{2}\right]$ and $[\mathrm{Cu}(R, S-$ $\mathrm{Me}_{6}$ cyclam) $\left(\mathrm{NO}_{3}\right)_{2}$ ] were synthesized following procedures previously reported. ${ }^{21,27}$

For all syntheses, a mixture of $\left[\mathrm{UO}_{2}\left(\mathrm{NO}_{3}\right)_{2}\left(\mathrm{H}_{2} \mathrm{O}\right)_{2}\right] \cdot 4 \mathrm{H}_{2} \mathrm{O}(35 \mathrm{mg}, 0.07 \mathrm{mmol}), \mathrm{tdcH}_{2}$ (17 mg, $0.10 \mathrm{mmol})$, and additional reactants in demineralized water $(0.6 \mathrm{~mL})$ and organic cosolvent $(0.2 \mathrm{~mL})$ was placed in a $10 \mathrm{~mL}$ tightly closed glass vessel and heated at $140{ }^{\circ} \mathrm{C}$ in a sand bath, and the crystals were grown in the hot, pressurized solution (and not as a result of a 
final return to ambient conditions). In all cases, only a few crystals were obtained, which precluded further chemical characterization. A summary of the synthesis conditions (cosolvent, additional reactants, and heating duration) is given in Table 1 .

Table 1. Summary of the Synthesis Conditions

\begin{tabular}{|c|c|c|c|}
\hline Compound & $\begin{array}{c}\text { Organic } \\
\text { Cosolvent } \\
\end{array}$ & Additional Reactants & Duration \\
\hline$\left[\mathrm{UO}_{2}(\mathrm{tdc})(\mathrm{DMF})\right](\mathbf{1})$ & DMF & & $24 \mathrm{~h}$ \\
\hline$\left[\mathrm{PPh}_{3} \mathrm{Me}\right]\left[\mathrm{UO}_{2}(\mathrm{tdc})(\mathrm{HCOO})\right](\mathbf{2})$ & DMF & $\mathrm{PPh}_{3} \mathrm{MeBr}(36 \mathrm{mg}, 0.10 \mathrm{mmol})$ & $3 \mathrm{~d}$ \\
\hline$\left[\mathrm{C}\left(\mathrm{NH}_{2}\right)_{3}\right]\left[\mathrm{H}_{2} \mathrm{NMe}_{2}\right]_{2}\left[\left(\mathrm{UO}_{2}\right)_{3}(\mathrm{tdc})_{4}(\mathrm{HCOO})\right](\mathbf{3})$ & DMF & $\mathrm{C}\left(\mathrm{NH}_{2}\right)_{3} \mathrm{NO}_{3}(24 \mathrm{mg}, 0.20 \mathrm{mmol})$ & $2 \mathrm{~m}$ \\
\hline$\left[\mathrm{UO}_{2}(\mathrm{tdc})_{2} \mathrm{Ni}(\mathrm{cyclam})\right](\mathbf{4})$ & DMF & {$\left[\mathrm{Ni}(\right.$ cyclam $\left.)\left(\mathrm{NO}_{3}\right)_{2}\right](20 \mathrm{mg}, 0.05 \mathrm{mmol})$} & $10 \mathrm{~d}$ \\
\hline$\left[\mathrm{Cu}\left(R, S-\mathrm{Me}_{6}\right.\right.$ cyclam $\left.)\left(\mathrm{H}_{2} \mathrm{O}\right)\right]\left[\mathrm{UO}_{2}(\mathrm{tdc})_{2}\right] \cdot \mathrm{H}_{2} \mathrm{O}(\mathbf{5})$ & DMF & {$\left[\mathrm{Cu}\left(R, S-\mathrm{Me}_{6}\right.\right.$ cyclam $\left.)\left(\mathrm{NO}_{3}\right)_{2}\right](24 \mathrm{mg}, 0.05 \mathrm{mmol})$} & $5 \mathrm{~d}$ \\
\hline$\left[\mathrm{Zn}(\mathrm{phen})_{3}\right]\left[\left(\mathrm{UO}_{2}\right)_{2}(\mathrm{tdc})_{3}\right] \cdot 2 \mathrm{H}_{2} \mathrm{O} \cdot 3 \mathrm{CH}_{3} \mathrm{CN}(\mathbf{6})$ & $\mathrm{CH}_{3} \mathrm{CN}$ & $\mathrm{Zn}\left(\mathrm{NO}_{3}\right)_{2} \cdot 6 \mathrm{H}_{2} \mathrm{O}(30 \mathrm{mg}, 0.10 \mathrm{mmol})$; phen $(18 \mathrm{mg}, 0.10 \mathrm{mmol})$ & $5 \mathrm{~d}$ \\
\hline$\left[\mathrm{PPh}_{4}\right]_{2}\left[\left(\mathrm{UO}_{2}\right)_{2}(\mathrm{tdc})_{3}\right] \cdot 2 \mathrm{H}_{2} \mathrm{O}(7)$ & DMF & $\mathrm{PPh}_{4} \mathrm{Br}(42 \mathrm{mg}, 0.10 \mathrm{mmol})$ & $10 \mathrm{~d}$ \\
\hline
\end{tabular}

Crystallography. Data collections were performed at 100(2) K on a Bruker D8 Quest diffractometer using an Incoatec Microfocus Source $(\mathrm{I} \mu \mathrm{S} 3.0 \mathrm{Mo})$ and a PHOTON III area detector, and operated with APEX3 ${ }^{28}$ The data were processed with SAINT, ${ }^{29}$ and empirical absorption corrections were made with SADABS. ${ }^{30,31}$ The structures were solved by intrinsic phasing with SHELXT, ${ }^{32}$ and refined by full-matrix least-squares on $F^{2}$ with SHELXL, ${ }^{33}$ using the ShelXle interface. ${ }^{34}$ When present, hydrogen atoms bound to nitrogen or oxygen atoms were found on difference electron density maps, except for compound 7, and they were refined with restraints. The other hydrogen atoms were introduced at calculated positions and treated as riding atoms with an isotropic displacement parameter equal to 1.2 times that of the parent atom (1.5 for $\mathrm{CH}_{3}$ ). The Flack parameter in complex 5 was $0.007(3)$. The SQUEEZE ${ }^{35}$ software was used to subtract the contribution of disordered solvent molecules to the structure factors for compound 3. Crystal data and structure refinement parameters are given in Table 2. Drawings were made with ORTEP- $3^{36}$ and VESTA, ${ }^{37}$ and topological analyses with ToposPro. ${ }^{38}$ 
Table 2. Crystal Data and Structure Refinement Details

\begin{tabular}{|c|c|c|c|c|c|c|c|}
\hline & 1 & 2 & 3 & 4 & 5 & 6 & 7 \\
\hline chemical formula & $\mathrm{C}_{9} \mathrm{H}_{9} \mathrm{NO}_{7} \mathrm{SU}$ & $\mathrm{C}_{26} \mathrm{H}_{21} \mathrm{O}_{8} \mathrm{PSU}$ & $\mathrm{C}_{30} \mathrm{H}_{31} \mathrm{~N}_{5} \mathrm{O}_{24.5} \mathrm{~S}_{4} \mathrm{U}_{3}$ & $\mathrm{C}_{22} \mathrm{H}_{28} \mathrm{~N}_{4} \mathrm{NiO}_{10} \mathrm{~S}_{2} \mathrm{U}$ & $\mathrm{C}_{28} \mathrm{H}_{44} \mathrm{CuN}_{4} \mathrm{O}_{12} \mathrm{~S}_{2} \mathrm{U}$ & $\mathrm{C}_{60} \mathrm{H}_{43} \mathrm{~N}_{9} \mathrm{O}_{18} \mathrm{~S}_{3} \mathrm{U}_{2} \mathrm{Zn}$ & $\mathrm{C}_{66} \mathrm{H}_{50} \mathrm{O}_{18} \mathrm{P}_{2} \mathrm{~S}_{3} \mathrm{U}_{2}$ \\
\hline$M\left(\mathrm{~g} \mathrm{~mol}^{-1}\right)$ & 513.26 & 762.49 & 1695.93 & 869.34 & 994.36 & 1815.64 & 1765.24 \\
\hline cryst syst & monoclinic & monoclinic & monoclinic & monoclinic & monoclinic & monoclinic & orthorhombic \\
\hline space group & $P 2_{1} / n$ & $P 2_{1} / n$ & $C 2 / m$ & $P 2{ }_{1} / c$ & $C c$ & $P 2_{1} / c$ & Pbca \\
\hline$a(\AA)$ & $8.4399(3)$ & $10.5122(3)$ & $22.7352(11)$ & $10.0528(6)$ & $19.8821(6)$ & $18.3336(5)$ & $17.8772(4)$ \\
\hline$b(\AA)$ & $11.0783(3)$ & $18.3921(5)$ & $27.2585(12)$ & $8.7729(5)$ & $9.7129(3)$ & $18.4172(5)$ & $18.2236(5)$ \\
\hline$c(\AA)$ & $14.2842(4)$ & 13.6163(4) & $8.1965(3)$ & $15.4174(8)$ & $18.0419(4)$ & $19.7929(5)$ & $39.4417(10)$ \\
\hline$\beta(\operatorname{deg})$ & $106.1400(14)$ & $101.7433(13)$ & $102.9731(18)$ & $91.668(2)$ & $93.3551(11)$ & $113.9722(10)$ & \\
\hline$V\left(\AA^{3}\right)$ & $1282.93(7)$ & $2577.49(13)$ & $4949.9(4)$ & $1359.12(13)$ & $3478.15(17)$ & $6106.7(3)$ & $12849.6(6)$ \\
\hline$Z$ & 4 & 4 & 4 & 2 & 4 & 4 & 8 \\
\hline reflns collcd & 103748 & 130920 & 89081 & 110400 & 132670 & 473806 & 174056 \\
\hline indep reflns & 3874 & 7846 & 4783 & 2582 & 8659 & 18625 & 12194 \\
\hline obsd reflns $[I>2 \sigma(I)]$ & 3762 & 7421 & 4509 & 2465 & 8517 & 17377 & 9676 \\
\hline$R_{\text {int }}$ & 0.042 & 0.036 & 0.044 & 0.046 & 0.053 & 0.054 & 0.092 \\
\hline params refined & 189 & 335 & 322 & 190 & 470 & 857 & 820 \\
\hline$R_{1}$ & 0.011 & 0.013 & 0.034 & 0.025 & 0.017 & 0.015 & 0.041 \\
\hline$w R_{2}$ & 0.026 & 0.031 & 0.079 & 0.060 & 0.033 & 0.037 & 0.079 \\
\hline$S$ & 1.076 & 1.037 & 1.139 & 1.234 & 1.033 & 1.028 & 1.082 \\
\hline$\Delta \rho_{\min }\left(\mathrm{e} \AA^{-3}\right)$ & -0.34 & -0.40 & -1.24 & -1.37 & -0.40 & -1.01 & -1.10 \\
\hline$\Delta \rho_{\max }\left(\mathrm{e} \AA^{-3}\right)$ & 0.85 & 0.78 & 1.88 & 2.14 & 0.41 & 1.74 & 1.79 \\
\hline
\end{tabular}

\section{RESULTS}

The unique uranyl cation in the complex $\left[\mathrm{UO}_{2}(\operatorname{tdc})(\mathrm{DMF})\right](\mathbf{1})$ is chelated in $\kappa^{2} O, O^{\prime}$ mode by one carboxylate group, with two more carboxylate donors and the coordinated DMF molecule giving the usual pentagonal-bipyramidal coordination environment for the uranium centre [UO bond lengths, $1.7650(13)$ and 1.7732(13) $\AA$ for oxo groups; $2.4181(11)$ and 2.5013(12) $\AA$ for the chelating carboxylate group; 2.3389(13) and 2.3440(12) $\AA$ for the monodentate carboxylate groups; 2.3205(12) $\AA$ for DMF] (Figure 1). This complex is quite unlike either of the two known polymorphic forms of the triperiodic solvates $\left[\mathrm{UO}_{2}(\mathrm{tdc})(\mathrm{NMP})\right]^{12}$ in that the polymer present is monoperiodic, though double-stranded. The chain, parallel to [010], is built up by alternation of 8- and 16-membered rings and it displays centrosymmetric diuranacyclic units where the ligand binding is such that one carboxylate forms a 4-membered $\left(\kappa^{2} O, O^{\prime}\right)$ chelate ring and the other acts as a $\mu_{2-\kappa}{ }^{1} O ; \kappa^{1} O^{\prime}$ bridge, a form already known in other $\operatorname{tdc}^{2-}$ complexes with uranyl. ${ }^{9,11}$ Most relevant to the present work is the simple fact that $\mathbf{1}$ contains intact DMF, even after a reaction period of $24 \mathrm{~h}$ (Table 1). This is significant because two other complexes 

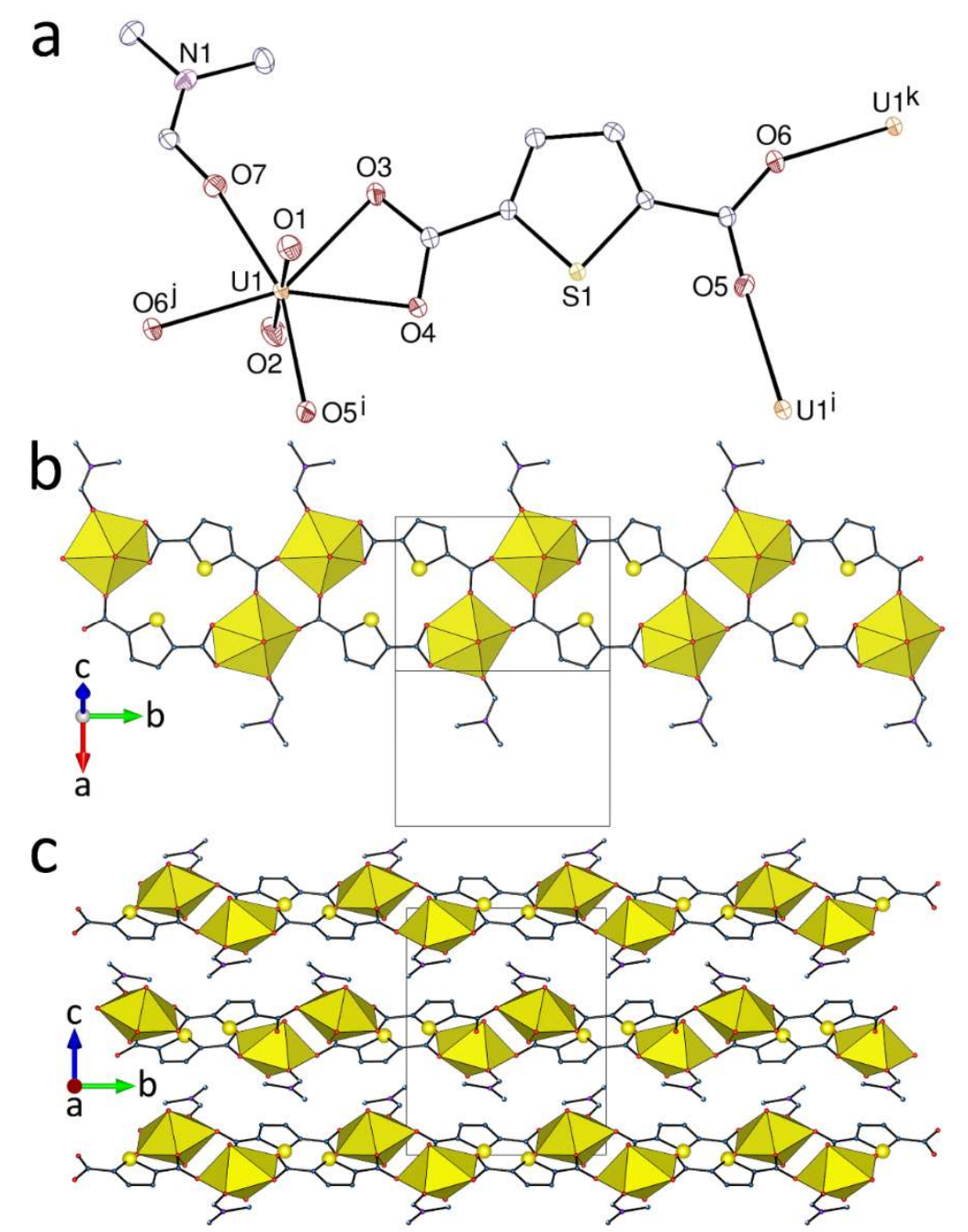

Figure 1. (a) View of complex 1 with displacement ellipsoids shown at the $50 \%$ probability level. Symmetry codes: $\mathrm{i}=2-x, 2-y, 1-z ; \mathrm{j}=x, y-1, z ; \mathrm{k}=x, y+1, z$. (b) View of the monoperiodic assembly showing uranium coordination polyhedra. (c) View of the packing. Hydrogen atoms are omitted, and only one position of the disordered DMF molecule is shown in all views.

isolated (see ahead) have compositions reflecting the occurrence of DMF hydrolysis. While it is conceivable that DMF hydrolysis reaches an equilibrium position under the conditions used, if not it is clear that optimization of yields in these syntheses may require truly extended reaction periods.

In the complex $\left[\mathrm{PPh}_{3} \mathrm{Me}\right]\left[\mathrm{UO}_{2}(\mathrm{tdc})(\mathrm{HCOO})\right](2)$, the ratio $\mathrm{U} /$ carboxylate of $1: 3$ is achieved as a results of the presence of a formate ligand, presumably arising from DMF hydrolysis, as commonly observed in solvo-hydrothermal syntheses. Although this 
stoichiometry does result in hexagonal-bipyramidal coordination of $\mathrm{U}^{\mathrm{VI}}[\mathrm{U}-\mathrm{O}$ bond lengths, $1.7793(11)$ and $1.7797(11) \AA$ for oxo groups; $2.4315(11)-2.4866(11) \AA$ for carboxylate groups], only a simple monoperiodic, single-stranded polymer running along [010] is formed in which all carboxylate groups, as expected, display $\kappa^{2} O, O^{\prime}$-chelation (Figure 2). These

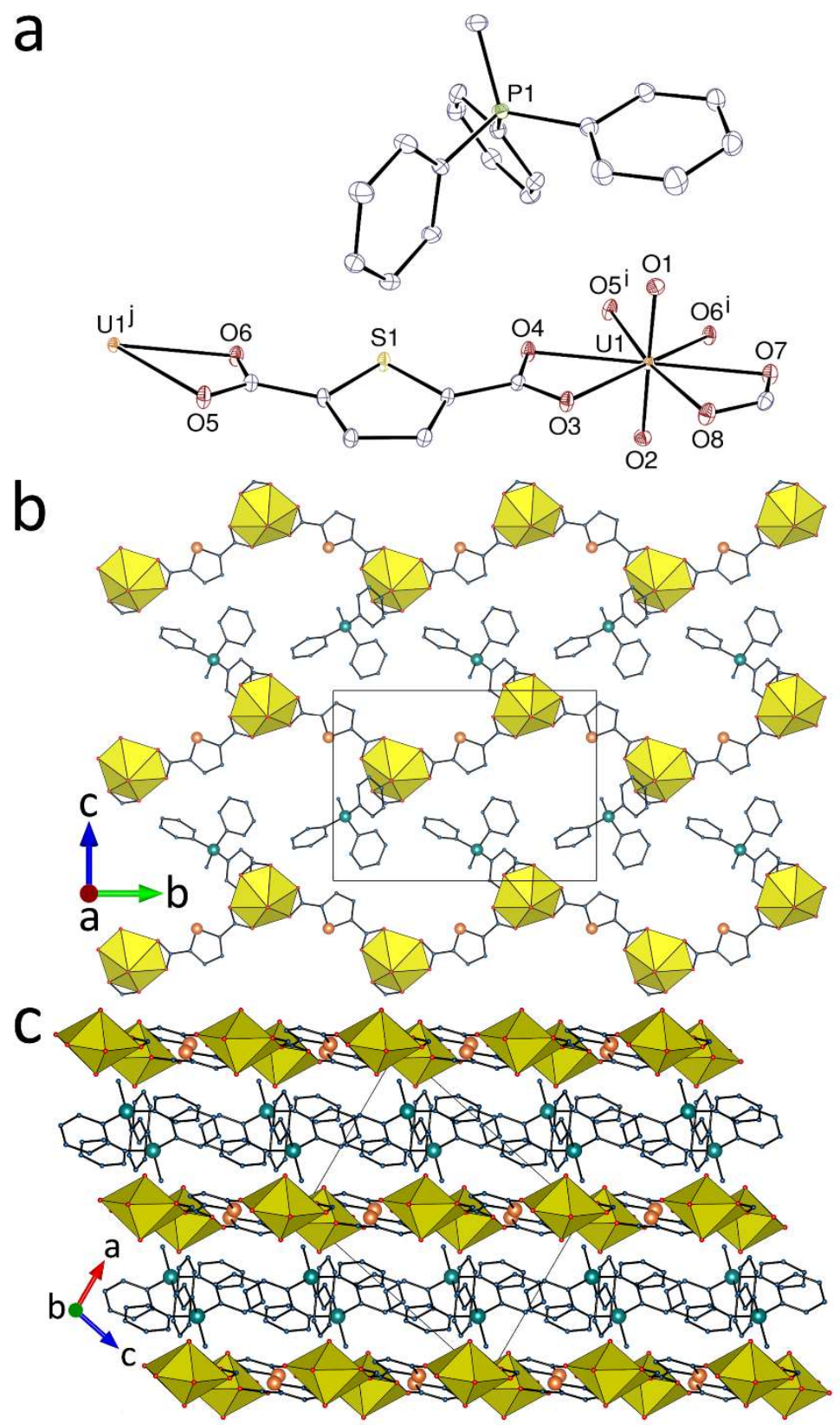

Figure 2. (a) View of compound 2 with displacement ellipsoids shown at the $50 \%$ probability level. Symmetry codes: Symmetry codes: $\mathrm{i}=3 / 2-x, y-1 / 2,3 / 2-z ; \mathrm{j}=3 / 2-x, y+1 / 2,3 / 2-z$. (b) Arrangement of chains in one layer with counterions. (c) Packing with layers viewed edge-on. 


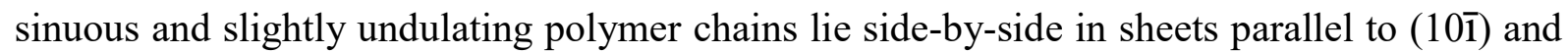
separated by $\sim 5 \AA$, with sheets of the cations lying between those of the polymer. The $\mathrm{PPh}_{3} \mathrm{Me}^{+}$ cations are associated in centrosymmetric pairs through an orthogonal phenyl embrace involving four aromatic rings, as commonly observed for the related $\mathrm{PPh}_{4}{ }^{+}$cation, ${ }^{39}$ with a $\mathrm{P} \ldots \mathrm{P}$ separation of $6.8309(8) \AA$ and two vertex-to-face $\mathrm{CH} \cdots \pi$ contacts $[\mathrm{H} \cdots$ centroid distance, 2.51 $\AA$; C-H $\cdots$ centroid angle, $159^{\circ}$ ]. This interaction is apparent on the Hirshfeld surface (HS $)^{40,41}$ of the cation, which shows also the presence of several $\mathrm{CH} \cdots \mathrm{O}$ hydrogen bonds, ${ }^{42,43}$ a ubiquitous feature of such complexes, as well as a possible interaction between a proton of the cation and the thiophene ring $\left[\mathrm{H} \cdots\right.$ centroid distance, $2.75 \AA$; $\mathrm{C}-\mathrm{H} \cdots$ centroid angle, $\left.148^{\circ}\right]$. The packing does not display any significant solvent-accessible space and its Kitaigorodski packing index (KPI, evaluated with PLATON ${ }^{44}$ ) is 0.70 .

The complex $\left[\mathrm{C}\left(\mathrm{NH}_{2}\right)_{3}\right]\left[\mathrm{H}_{2} \mathrm{NMe}_{2}\right]_{2}\left[\left(\mathrm{UO}_{2}\right)_{3}(\mathrm{tdc})_{4}(\mathrm{HCOO})\right](3)$, shown in Figure 3, deposited after an exceptionally long reaction period of 2 months, is unusual in containing both products of DMF hydrolysis, formate and dimethylammonium, one other case of such coexistence having been reported recently. ${ }^{45}$ The two inequivalent uranium centres are both tris- $\kappa^{2} O, O^{\prime}$-chelated, one by three $\operatorname{tdc}^{2-}$ anions and the other by two $\operatorname{tdc}^{2-}$ and one formate anions [U-O bond lengths, 1.762(6)-1.772(5) Å for oxo groups; 2.431(6)-2.481(5) $\AA$ for carboxylate groups]. The ratio U/carboxylate of 1:3 is once again not associated with honeycomb polymer formation due to the chain truncation resulting from formate coordination, but the polymer present is quite different to that in $\mathbf{2}$, now being a ladderlike, monoperiodic chain directed along [010] in which tetra- and hexa-uranacyclic units alternate, the latter being bounded by the formato groups on its two lateral wings. As in the true honeycomb sheets of other complexes, the larger rings partially include one of the cations, the disordered guanidinium ion, while the dimethylammonium ions are located close to, but outside the smaller rings. Both cations are associated with the polymeric chain by $\mathrm{NH} \cdots \mathrm{O}$ hydrogen bonding involving oxo and 


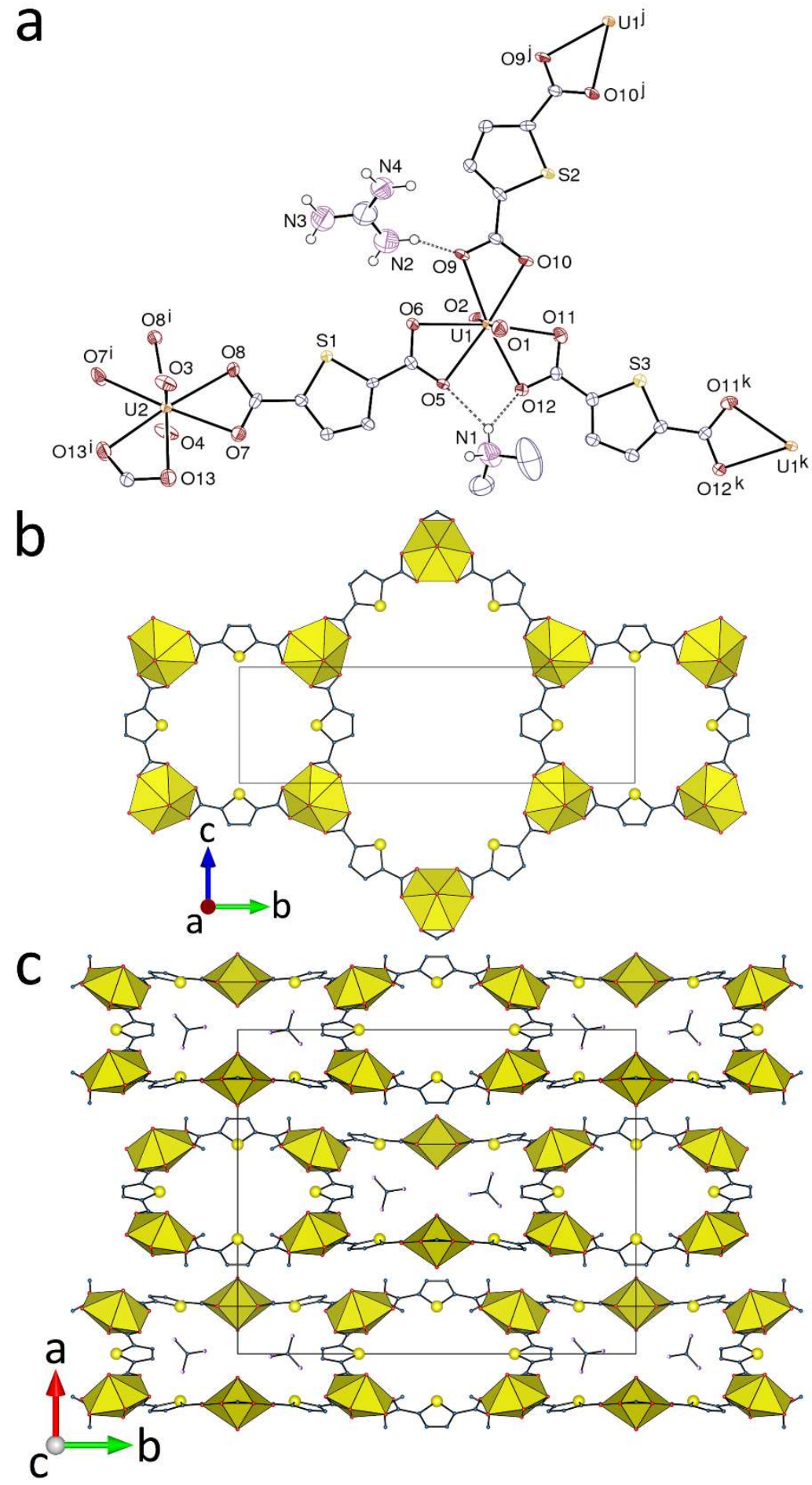

Figure 3. (a) View of compound 3 with displacement ellipsoids shown at the 50\% probability level and hydrogen bonds shown as dashed lines. Only one position of the disordered counterion is represented. Symmetry codes: $\mathrm{i}=$ $x, 1-y, z ; \mathrm{j}=1-x, y,-z-1 ; \mathrm{k}=x, 2-y, z$. (b) The monoperiodic assembly. (c) View of the packing.

carboxylato oxygen atoms $[\mathrm{N} \cdots \mathrm{O}$ distances, 2.639(15)-3.483(17) $\AA$; N-H $\cdots \mathrm{O}$ angles, $113-$ $168^{\circ}$ ]. Notwithstanding some differences in detail (in particular concerning the exo/endo 
position of sulfur atoms with respect to the rings), these chains are close to those found in $[4,6-$ MebipyH $]_{3}\left[\left(\mathrm{UO}_{2}\right)_{3}(\mathrm{tdc})_{4}\left(\mathrm{CH}_{3} \mathrm{CO}_{2}\right)\right] \cdot(4,6-\mathrm{Mebipy}) \cdot \mathrm{H}_{2} \mathrm{O} \quad$ (4,6-Mebipy $=$ 4,4',6,6'-tetramethyl2,2'-bipyridine), in which acetate replace formate anions and the disordered guests occupy the larger rings. ${ }^{9}$ Viewed down [001], polymer chains in $\mathbf{3}$ appear to stack into thick layers parallel to (100) within which hydrogen bonding interactions with the cations are completely internal.

Where axial coordination to a metal ion/macrocycle complex does occur, as in $\left[\mathrm{UO}_{2}(\mathrm{tdc})_{2} \mathrm{Ni}(\mathrm{cyclam})\right](4)$, a completely different polymer results, in which the ratio $\mathrm{U} / \mathrm{tdc}^{2-}$ is 1:2 (Figure 4). The unique uranium atom, located on an inversion centre, is here in its relatively uncommon square-bipyramidal (axially compressed octahedral) coordination, being bound to

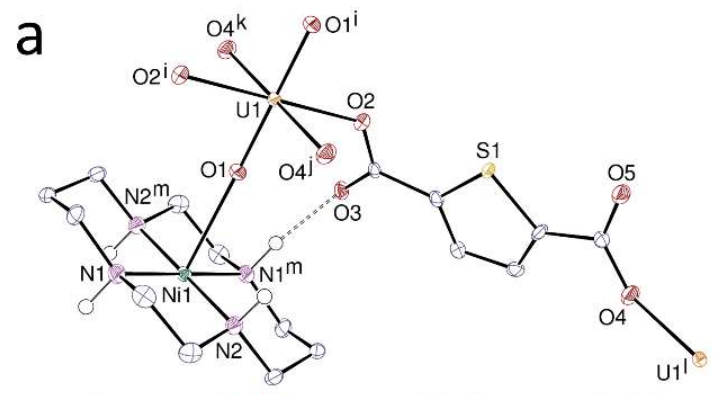

$\mathrm{b}$
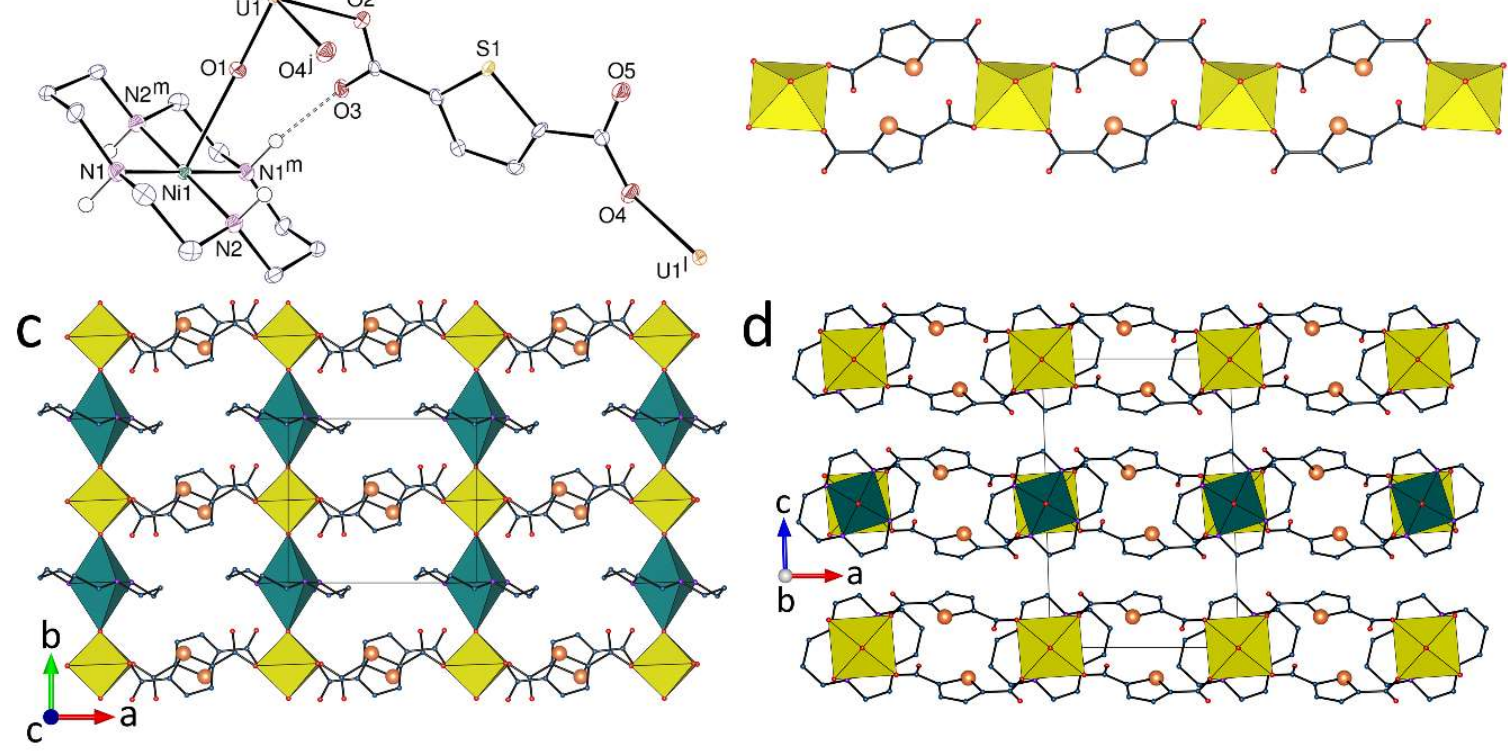

Figure 4. (a) View of compound 4 with displacement ellipsoids shown at the $50 \%$ probability level and the hydrogen bond shown as a dashed line. Symmetry codes: $\mathrm{i}=2-x, 1-y, 1-z ; \mathrm{j}=1-x, 1-y, 1-z ; \mathrm{k}=x+1, y$, $z ; 1=x-1, y, z ; \mathrm{m}=2-x, 2-y, 1-z$. (b) The monoperiodic subunit. (c) The diperiodic assembly with coordination polyhedra yellow for uranium and green for nickel. (d) Packing with layers viewed edge-on.

four equatorial oxygen atoms from four carboxylate groups, each in the $\kappa^{1} O$ monodentate mode [U-O bond lengths, 1.780(3) $\AA$ for oxo groups; 2.282(3) and 2.329(3) $\AA$ for carboxylate 
groups]. The basic polymeric subunit now consists of a monoperiodic daisy chain of 16membered diuranacyclic units parallel to [100], close to that found in the complex $\left(\mathrm{H}_{2} \mathrm{dpyz}\right)\left[\mathrm{UO}_{2}(\mathrm{tdc})_{2}\left(\mathrm{H}_{2} \mathrm{O}\right)\right] \cdot \mathrm{H}_{2} \mathrm{O}\left(\mathrm{H}_{2} \mathrm{dpyz}=1\right.$,4-di(pyridinium $)$ piperazine $),{ }^{11}$ although a fifth equatorial donor, in the form of a water molecule, is present here. The same bis(monodentate) coordination mode of the ligand is also found in the simple binuclear species $\left[\mathrm{UO}_{2}(\mathrm{tdc})(\text { terpy) }]_{2} \cdot{ }^{6,7}\right.$ In addition to being bound to the four nitrogen atoms of the macrocycle, $\mathrm{Ni}^{\mathrm{II}}$, located on an inversion centre, is axially bound to two uranyl oxo groups, its environment being an axially elongated octahedron $[\mathrm{Ni}-\mathrm{N}$ bond lengths, 1.934(4) and 1.942(4) $\AA$; Ni-O bond length, 2.607(3) $\AA$ ]. Although not frequent, oxo bonding of $\mathrm{Ni}^{\mathrm{II}}$ to uranyl has also been found in $\left[\left(\mathrm{UO}_{2}\right)_{2}(\mathrm{btc})_{2} \mathrm{Ni}(\mathrm{cyclam})\right]\left(\mathrm{btc}^{3-}=1,2,4\right.$-benzenetricarboxylate $),{ }^{46}$ the $\mathrm{Ni}-\mathrm{O}$ bond length being somewhat shorter in this case, at 2.516(4) $\AA$, while the $\mathrm{U}=\mathrm{O}-\mathrm{Ni}$ angle of $157.5(2)^{\circ}$ is smaller than that in $\mathbf{4}, 178.20(16)^{\circ}$. Additionally and as usual, ${ }^{27}$ cyclam is hydrogen bonded to carboxylate groups, here from two different polymeric chains [ $\mathrm{N} \cdots \mathrm{O}$ distances, $2.828(5)$ and $2.872(5) \AA ; \mathrm{N}-\mathrm{H} \cdots \mathrm{O}$ angles, $161(4)$ and $\left.164(4)^{\circ}\right]$. As a result of diaxial coordination of $\mathrm{Ni}^{\mathrm{II}}$, the monoperiodic chains are linked into uninodal diperiodic networks parallel to (001), which can be seen as having the sql topological type, with the $\operatorname{tdc}^{2-}$ ligands making double links between the uranium nodes. The packing is compact (KPI, 0.71), but no particularly notable interlayer weak interaction is apparent.

The influence of small changes in the nature of the countercation on the polymer formed is well illustrated by the structure of $\left[\mathrm{Cu}\left(R, S-\mathrm{Me}_{6} \operatorname{cyclam}\right)\left(\mathrm{H}_{2} \mathrm{O}\right)\right]\left[\mathrm{UO}_{2}(\mathrm{tdc})_{2}\right] \cdot \mathrm{H}_{2} \mathrm{O}(\mathbf{5})$, which is quite different from that of 4 , although the $U / \operatorname{tdc}^{2-}$ ratio of $1: 2$ is the same. The unique uranium atom is here in a pentagonal-bipyramidal environment, being $\kappa^{2} O, O^{\prime}$-chelated by one $\operatorname{tdc}^{2-}$ ligand and linked to three additional ligands through a single oxygen donor [ $\mathrm{U}-\mathrm{O}$ bond lengths, 1.780(3) and 1.781(3) $\AA$ for oxo groups; 2.476(2) and 2.479(3) $\AA$ for the chelating carboxylate group; 2.311(3)-2.316(3) $\AA$ for the monodentate carboxylate groups] (Figure 5). One of the 


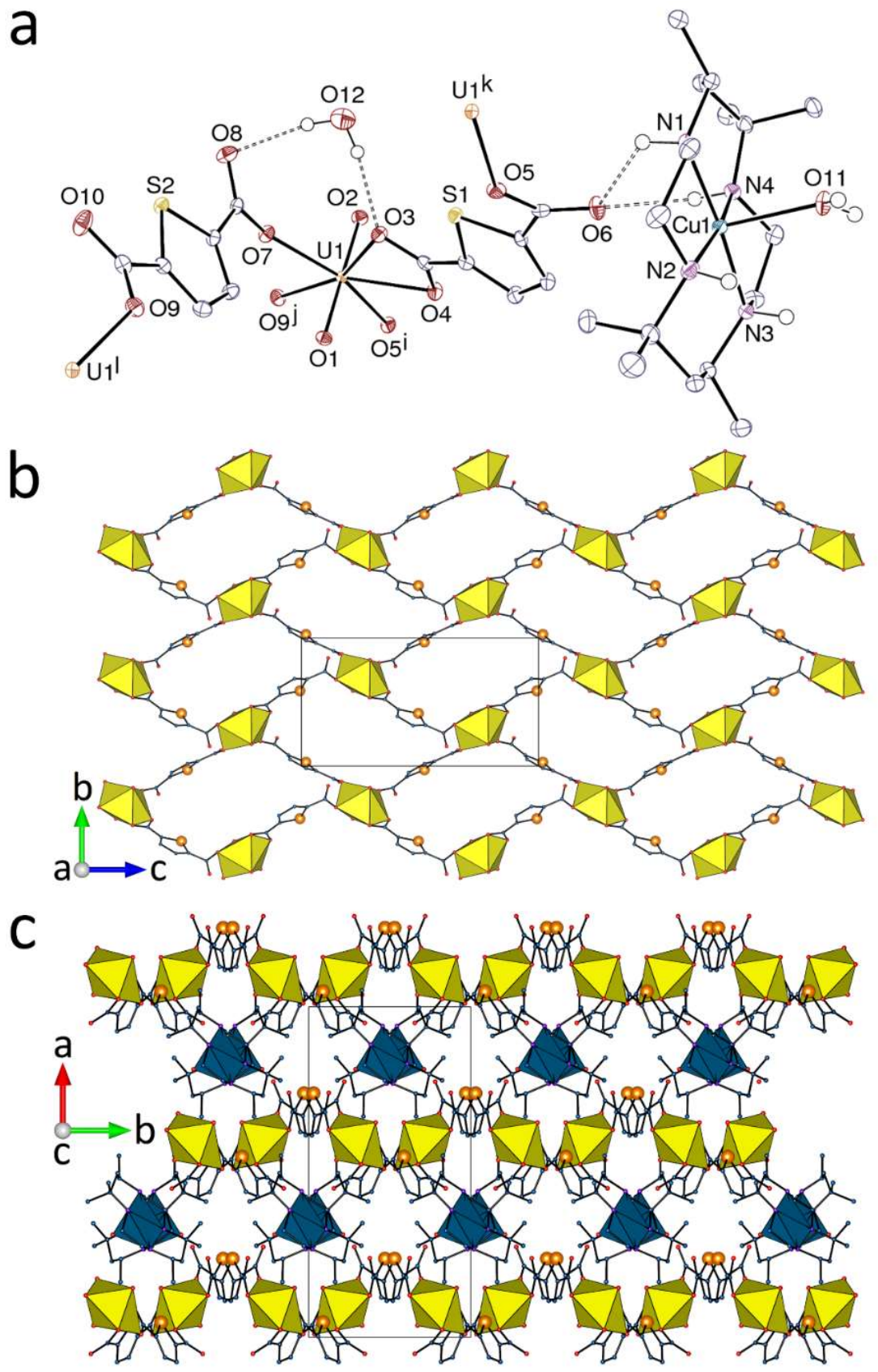

Figure 5. (a) View of compound 5 with displacement ellipsoids shown at the 50\% probability level and hydrogen bonds shown as dashed lines. Symmetry codes: $\mathrm{i}=x, 1-y, z-1 / 2 ; \mathrm{j}=x, 2-y, z-1 / 2 ; \mathrm{k}=x, 1-y, z+1 / 2 ; 1=x$, $2-y, z+1 / 2$. (b) The diperiodic assembly. (c) Packing with layers viewed edge-on. Uranium coordination polyhedra are yellow and those of copper blue.

$\operatorname{tdc}^{2-}$ ligands has one carboxylate group $\kappa^{2} O, O^{\prime}$-chelating and the other $\kappa^{1} O$-monodentate, while the other has two monodentate groups. Both ligands are thus simple links, as in $\mathbf{4}$, and the 
uranium centres are 4-coordinated (4-c) nodes, so that the diperiodic network formed, parallel to (100), has the $\left\{4^{4} \cdot 6^{2}\right\}$ vertex symbol and the sql topological type. This polymer can be regarded as built up by fusion of strongly puckered, 32-membered tetra-uranacyclic units, with all sulfur atoms pointing in the same direction. Interactions between the polymer and the countercation are exclusively of the hydrogen bonding type, involving both the water molecule coordinated axially to $\mathrm{Cu}^{\mathrm{II}}$ and the $\mathrm{NH}$ units of the $R, S$-Me ${ }_{6}$ cyclam macrocycle, and oxo and carboxylato acceptors $[\mathrm{O} / \mathrm{N} \cdots \mathrm{O}$ distances, 2.690(4)-3.012(4) $\AA ; \mathrm{O} / \mathrm{N}-\mathrm{H} \cdots \mathrm{O}$ angles, 139(4)$\left.170(5)^{\circ}\right]$, while the solvent water molecule is hydrogen bonded to two carboxylate groups from the same layer $\left(R_{2}^{2}(8)\right.$ ring in graph set notation $\left.{ }^{47,48}\right)$, the packing being space-free (KPI, 0.70). Whatever material crystallizes from a solvothermal reaction mixture is the least soluble species under the given conditions and its nature is not necessarily directly related to the composition of that mixture, so that rational exploitation of the method is difficult. Despite this caveat, it is significant that the structure of complex $\mathbf{5}$ contains a polymer form not previously observed in any uranyl ion complex of $\operatorname{tdc}^{2-}$.

The compound $\left[\mathrm{Zn}(\text { phen })_{3}\right]\left[\left(\mathrm{UO}_{2}\right)_{2}(\mathrm{tdc})_{3}\right] \cdot 2 \mathrm{H}_{2} \mathrm{O} \cdot 3 \mathrm{CH}_{3} \mathrm{CN}(\mathbf{6})$ is a relative of $\mathrm{Fe}^{\mathrm{II}}-$ and $\mathrm{Ni}^{\text {II }}$-containing species where it has been found that the exact composition of the isolated crystals depends upon the (co)solvent. ${ }^{8,10}$ The two inequivalent uranium atoms are in similar hexagonal-bipyramidal environments, being both tris- $\kappa^{2} O, O^{\prime}$-chelated [U-O bond lengths,

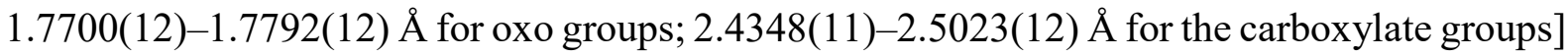
(Figure 6). The uranium atoms are thus 3-c nodes and the ligands simple links in the resulting diperiodic hcb network (vertex symbol $\left\{6^{3}\right\}$ ) parallel to (101), with the sulfur atoms pointing alternately inside and outside each hexanuclear ring. Acetonitrile as cosolvent does not appear to have the same influence as $N$-methyl-2-pyrrolidone (NMP), ${ }^{10}$ although it is a component of 


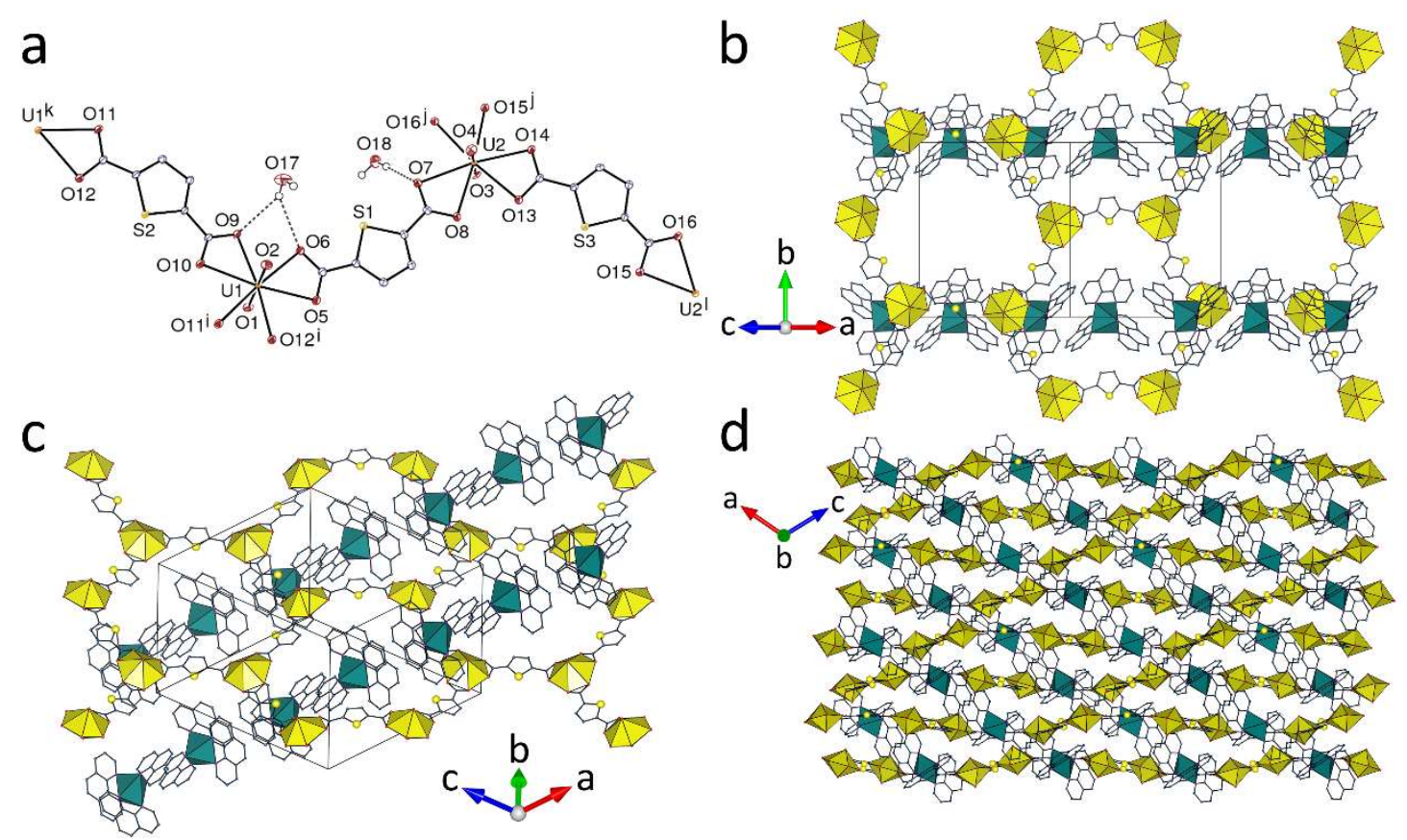

Figure 6. (a) View of compound 6 with displacement ellipsoids shown at the 50\% probability level and hydrogen bonds shown as dashed lines. Symmetry codes: $\mathrm{i}=-x, y-1 / 2,3 / 2-z ; \mathrm{j}=1-x, y+1 / 2,1 / 2-z ; \mathrm{k}=-x, y+1 / 2$, $3 / 2-z ; 1=1-x, y-1 / 2,1 / 2-z$. (b and c) Two views of the diperiodic assembly with two inclined chains of counterions. (d) Packing with layers viewed edge-on and horizontal. Uranium coordination polyhedra are yellow and those of zinc green.

the crystal, so that the closest comparison of the present structure is with that of the $\mathrm{Fe}^{\mathrm{II}}$ analogue prepared in pure water, ${ }^{8}$ since in neither case is there interpenetration of the diperiodic polymer units. As in the $\mathrm{Fe}^{\mathrm{II}}$ complex, there is a partial projection of the countercation into the large rings of the honeycomb sheet, while additional partial inclusion of $\mathrm{CH}_{3} \mathrm{CN}$ in the rings replaces that of uncoordinated $\mathrm{H}_{2} \mathrm{tdc}$ in the $\mathrm{Fe}^{\mathrm{II}}$ system. The diperiodic sheets in $\mathbf{6}$ are very slightly more ruffled than those in the $\mathrm{Fe}^{\mathrm{II}}$-containing species and, while interactions with the cations may be important in producing their honeycomb form, acetonitrile may be added to the variety of species which can accompany the cations in inclusion. An interesting feature of complex 6 appears when the geometry of the association of counterions and anionic layers is considered. Each $\left[\mathrm{Zn}(\mathrm{phen})_{3}\right]^{2+}$ cation is involved in two parallel-displaced $\pi$-stacking interactions with each of its two neighbours [centroid...centroid distances, 3.7489(11)- 
4.4102(10) Å; dihedral angles, $0-4.31(8)^{\circ}$; slippage, $1.48-2.86 \AA$ ], and orthogonal interactions between phen molecules are also found [shortest $\mathrm{H} \cdots$ centroid distance, $2.53 \AA$; $\mathrm{C}-\mathrm{H}$-..centroid angle, $168^{\circ}$ ]; these interactions are clearly apparent on the HS of the cation. This association of counterions through weak interactions gives rise to the formation of columns directed along [100], which are thus slanted with respect to the polymeric sheets (Figure 6d), so that they are threading the rings of successive layers in an oblique way (Figures $6 \mathrm{~b}$ and $\mathrm{c}$, in which only two counterion columns and a single layer are shown for clarity). This arrangement, which produces a tight packing (KPI, 0.71) may be viewed as an alternative to interpenetration of the polymeric sheets.

Although it also involves a phosphonium cation and has been obtained under conditions identical to those giving complex $2,\left[\mathrm{PPh}_{4}\right]_{2}\left[\left(\mathrm{UO}_{2}\right)_{2}(\mathrm{tdc})_{3}\right] \cdot 2 \mathrm{H}_{2} \mathrm{O}(7)$ is quite distinct from the former compound, having a different stoichiometry and including no formate anions. As in complex $\mathbf{6}$, the $\mathrm{U} / \mathrm{tdc}^{2-}$ ratio is $2: 3$, providing enough carboxylate units for the two inequivalent uranyl ions to form tris $\left(\kappa^{2} O, O^{\prime}\right)$ moieties [U-O bond lengths, 1.755(4)-1.767(5) $\AA$ for oxo groups; 2.445(4)-2.499(4) $\AA$ for the carboxylate groups] (Figure 7). Here also, the diperiodic network formed, parallel to (001), is of hcb topology and with sulfur atoms directed alternately inward and outward from each ring, but it has a strongly undulating form, with a thickness of $\sim 19 \AA$, to be compared to $\sim 5.5 \AA$ for $\mathbf{6}$, as a result of the tilting of one tdc ${ }^{2-}$ ligand out of three with respect to the equatorial plane of one uranyl ion (U2). The largest value for dihedral angles between uranyl equatorial planes and mean planes of $\operatorname{tdc}^{2-}$ ligands is $32.74(8)^{\circ}$ in 7 and $15.23(4)^{\circ}$ in $\mathbf{6}$, in keeping with the more pronounced undulations in the former. As a result, 3fold interpenetration of the parallel 2D type occurs in 7, as shown in Figure 8. In previous work, 

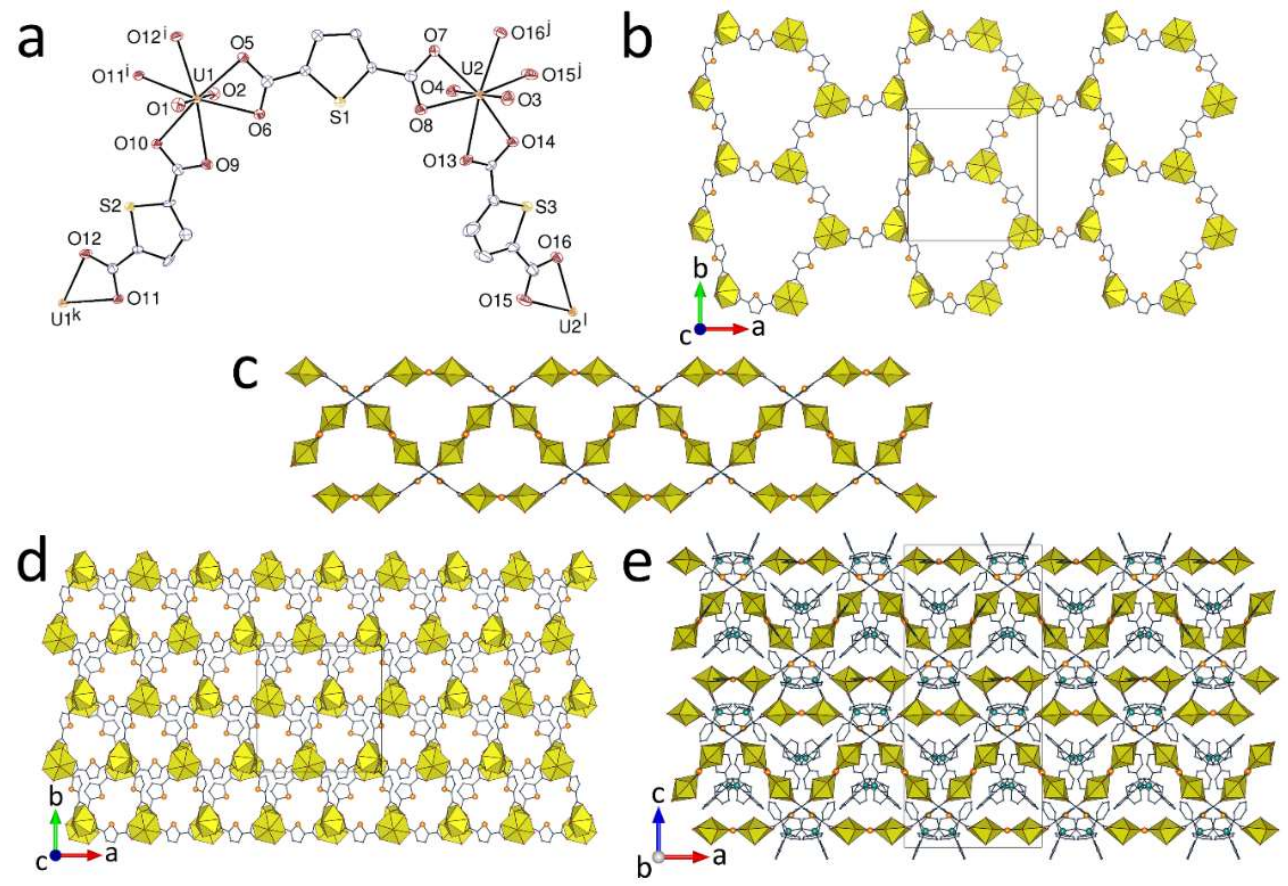

Figure 7. (a) View of compound 7 with displacement ellipsoids shown at the 50\% probability level. Symmetry codes: $\mathrm{i}=1-x, y+1 / 2,3 / 2-z ; \mathrm{j}=5 / 2-x, y+1 / 2, z ; \mathrm{k}=1-x, y-1 / 2,3 / 2-z ; 1=5 / 2-x, y-1 / 2, z$. (b) The diperiodic assembly. (c and d) Two views of the threefold interpenetrating diperiodic networks. (e) Packing with layers viewed edge-on.

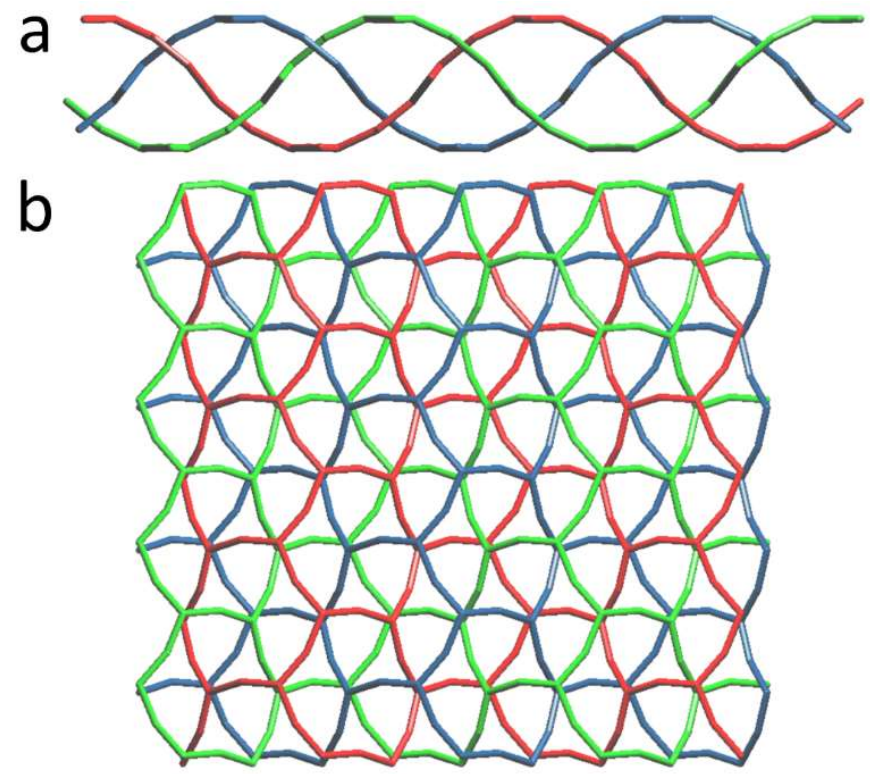

Figure 8. 3-Fold interpenetration of diperiodic networks in compound 7 shown edge-on (a) and side-on (b). 
the honeycomb form of the uranyl complex with $\operatorname{tdc}^{2-}$ has been shown to give inclined $2 \mathrm{D} \rightarrow$ $3 \mathrm{D}$ polycatenation in the presence of $\left[\mathrm{Ag}(\text { bipy })_{2}\right]^{+}$counterions (bipy $=2,2^{\prime}$-bipyridine), the sheets being quasi-planar, ${ }^{10}$ and 2-fold parallel 2D interpenetration with either $\mathrm{Na}^{+}$or piperazinium $\left(\mathrm{Hpz}^{+}\right)$counterions, the sheet thickness being $\sim 7 \AA$ in these cases. ${ }^{9,11}$ The $\operatorname{tdc}^{2-}$ ligand thus appears to have a propensity to give honeycomb networks of varying thickness when complexed to uranyl ions, and a regular progression is found with increasing thickness/undulation, from complex $\mathbf{6}$ in which the stacked honeycomb nets are threaded by oblique columns of counterions, to 2-fold parallel 2D interpenetrated nets and finally 3 -fold parallel 2D interpenetrated nets as in complex 7, the form obtained depending on the choice of counterions. In complex 7, channels parallel to [010] are formed both within and between the triple layers, which contain the $\mathrm{PPh}_{4}{ }^{+}$counterions (Figure 7e), and the KPI amounts to 0.67. There is however no close approach of the counterions to one another, with no P...P distance shorter than $9 \AA$, and the shorter aromatic centroid...centroid distances are between phenyl and thiophene rings.

\section{DISCUSSION}

While nitrogen donors in aza-aromatic carboxylates, ${ }^{49}$ or neutral oxygen donors, as in oxydiacetate $^{50}$ or tetrahydrofuran- ${ }^{51}$ and phenoxymethylene- ${ }^{52}$ polycarboxylates are known to provide both additional binding sites for uranium and for heterometal ions, in the particular case of $\operatorname{tdc}^{2-}$, however, its known complexes with uranyl ion involve no coordinative interactions of the sulfur atom, unsurprisingly given the oxophilic nature of $\mathrm{U}^{\mathrm{VI}}$ and the delocalisation of sulfur orbitals in the unsaturated heterocycle, and indeed appear to involve no interactions of any type other than dispersion for the sulfur (this is also true of the flexible analogue of this ligand, thiodiglycolate ${ }^{53}$ ). Thus, 2,5-thiophenedicarboxylate can be considered as a rigid, bridging ligand with little flexibility other than that due to rotation about the $\mathrm{C}-\mathrm{CO}_{2}{ }^{-}$bonds, and even 
that is moderate since no dihedral angle between the $\mathrm{CO}_{2}^{-}$groups and the thiophene rings exceeds $28^{\circ}$ in complexes $1-7$, and most are smaller than $15^{\circ}$. This makes $\operatorname{tdc}^{2-}$ akin to unfunctionalized dicarboxylates such as 1,3 -adamantanedicarboxylate ${ }^{54}$ or the slightly more flexible camphorate, ${ }^{55}$ though with a rather different steric profile and in fact with a significantly $(\sim 0.2 \AA)$ greater separation between the carboxylate groups than in either. This greater separation is a reflection of the fact that the thiophene ring causes the two $\mathrm{C}-\mathrm{CO}_{2}^{-}$ vectors to be at a much larger angle than in adamantane dicarboxylate or camphorate species even though there is a single atom bridging the two carbon atoms in all three.

This closer but inexact approach to diametric opposition of the carboxylates underlies some unique aspects of the coordination chemistry of $\operatorname{tdc}^{2-}$ with uranyl ion. In the presence of $2,2^{\prime}: 6^{\prime}, 2^{\prime \prime}$-terpyridine or its $4^{\prime}$-chloro derivative, ${ }^{6}$ its simplest coordination mode as a $\operatorname{bis}\left(\kappa^{1} O\right)$ bridging ligand is found in neutral, binuclear complexes where the thiophene rings lie close to parallel and are involved in aromatic...aromatic interactions. In the presence of the simple unidentate ligand $N$-methyl-2-pyrrolidone, ${ }^{12}$ again in neutral complexes, triperiodic frameworks are formed in which the ligand acts as a $\operatorname{bis}\left(\mu_{2}-\kappa^{1} O: \kappa^{1} O^{\prime}\right)$ bridge but where significant differences arise depending upon whether bridging occurs via syn,syn or syn,anti coordination of the carboxylates. No thiophene unit stacking is apparent in either case. Where the uranium/ $/ \mathrm{tcc}^{2-}$ ratio is $2: 3$ so that anionic polymers may form, the countercation has been shown $^{8}$ to have a significant influence on the overall structure, even though common diperiodic, honeycomb-form polymer sheets are present. With $\left[\mathrm{Fe}(\mathrm{phen})_{3}\right]^{2+}$, the sheets are very close to planar and lie in close pairs separated by the cations and with no apparent stacking of thiophene entities, whereas with $\left[\mathrm{Ni}(\text { phen })_{3}\right]^{2+}$ the nearly planar sheets, which include additional oxalate anions, are polycatenated, with cations occupying the cavities so defined. In both cases, the cation ligands project partially into the honeycomb cells which, unlike those of the uranyl ion complex of the truly linear ligand terephthalate in association with $\left[\mathrm{Cu}(\mathrm{phen}){ }_{2} \mathrm{Cl}\right]^{+}$which 
otherwise has a very similar structure to that of the $\left[\mathrm{Fe}(\mathrm{phen})_{3}\right]^{2+} / \mathrm{tdc}^{2-}$ species, have only approximate threefold and not sixfold symmetry. This is perhaps a reason for the unsymmetrical projection of the guests into the cells, this projection in the case of methylviologen countercations being associated with significant undulation of the diperiodic polymer. ${ }^{8}$ Like methylviologen, protonated aza-aromatics may act as countercations to anionic uranyl/tdc ${ }^{2-}$ complexes but in their neutral forms also act as ligands for $\mathrm{U}^{\mathrm{VI}}$ and both roles have been identified in a study of the influence of steric effects arising with methyl derivatives of 2,2'bipyridine. ${ }^{9}$ As well, where $\mathrm{Na}^{+}$was the countercation, interpenetration of markedly undulating honeycomb sheets was observed.

Further demonstration of countercation influences along with those of the cosolvent used in solvothermal syntheses has been provided by the use of $\left[\mathrm{Ni}(\text { bipy })_{3}\right]^{2+}$ and $\left[\mathrm{Co}\left(\left(\mathrm{NH}_{2}\right)_{2} \mathrm{Sar}\right)\right]^{3+}$ (bipy $=2,2^{\prime}$-bipyridine, sar $=3,6,10,13,16,19$-hexaazabicyclo[6.6.6]icosane) ${ }^{10}$ where the isolated complexes contained both fully and mono-deprotonated ligand in monoperiodic polymers in which $\operatorname{tdc}^{2-}$ acted as a bis $\left(\kappa^{2} O, O^{\prime}\right)$ bridge and $\mathrm{Htdc}^{-}$as a mono $\left(\kappa^{2} O, O^{\prime}\right)$ terminating ligand. Use again of $\left[\mathrm{Fe}(\text { phen })_{3}\right]^{2+}$ and $\left[\mathrm{Ni}(\text { phen })_{3}\right]^{2+}$, with NMP as organic cosolvent, did lead to structures containing the same diperiodic, honeycomb species as described previously but co-crystallised with mononuclear, hexagonal-bipyramidal trans-[ $\left.\mathrm{UO}_{2}(\mathrm{NMP})_{2}\left(\mathrm{NO}_{3}\right)_{2}\right]$ molecules. In the presence of $\mathrm{Ag}^{\mathrm{I}}$, complexes of $\mathrm{tdc}^{2-}$ could also be isolated but again their structure depended on the ligands bound to $\mathrm{Ag}^{\mathrm{I}}$. With $\left[\mathrm{Ag}\left(\mathrm{CH}_{3} \mathrm{CN}\right)_{2}\right]^{+}$, a diperiodic polymer is present but not one of a honeycomb form, instead involving a near-planar array of fused tetraand octanuclear uranacycles (fes topological type). With $\left[\operatorname{Ag}(\text { bipy })_{2}\right]^{+}$, there is a return to a diperiodic honeycomb polymer giving $2 \mathrm{D} \rightarrow 3 \mathrm{D}$ polycatenation.

Further examples of the remarkable versatility of $\mathrm{tdc}^{2-}$ as a ligand for uranyl ion have been obtained in a study ${ }^{11}$ of the influence of various $N$-heterocycles and their protonated forms on the structures of anionic polymers. Here, buckled diperiodic sheets involving both fused tri- 
and dinuclear and fused di- and tetranuclear uranacycles have been found as well as new examples of honeycomb sheets, both interpenetrated and not. In addition, another example of an unexpected reaction occurring during solvothermal synthesis of uranyl ion complexes was provided in the conversion of 1-(4'-pyridyl)-piperazine into 1,4-bis(4'-pyridyl)-piperazine. The crystallisation of an anionic polymer with small countercations can be regarded as a form of polymer imprinting but the sensitivity of uranyl/tdc ${ }^{2-}$ polymer structures to the nature of the cation shows that there is little probability that cation exchange could be accompanied by framework retention, even though photocatalytic activity is not lost by guest exchange. ${ }^{8,11}$

The two complexes $\mathbf{6}$ and $\mathbf{7}$ allow for a more detailed description of entangled networks in this family of compounds. For all reported examples (excluding that with additional oxalate anions), which all involve hcb diperiodic networks, Table 3 gives the width of the network and

Table 3. Overview of Entangled Networks in Uranyl Ion Complexes with tdc ${ }^{2-}$

\begin{tabular}{|c|c|c|c|}
\hline Compound & Width $(\AA)$ & Entanglement & Ref. \\
\hline$\left[\mathrm{Ag}(\text { bipy })_{2}\right]_{5}\left[\left(\mathrm{UO}_{2}\right)_{4}(\mathrm{tdc})_{6}\right] \cdot \mathrm{NO}_{3} \cdot 6 \mathrm{H}_{2} \mathrm{O}$ & $\sim 4.5$ & $2 \mathrm{D} \rightarrow 3 \mathrm{D}$ & 10 \\
\hline$\left[\mathrm{Zn}(\text { phen })_{3}\right]\left[\left(\mathrm{UO}_{2}\right)_{2}(\mathrm{tdc})_{3}\right] \cdot 2 \mathrm{H}_{2} \mathrm{O} \cdot 3 \mathrm{CH}_{3} \mathrm{CN}(\mathbf{6})$ & $\sim 5.5$ & "polythreading"a & this work \\
\hline $\begin{array}{l}\mathrm{Na}_{2}\left[\left(\mathrm{UO}_{2}\right)_{2}(\mathrm{tdc})_{3}\right] \cdot 4 \mathrm{H}_{2} \mathrm{O} \\
(\mathrm{Hpz})\left[\left(\mathrm{UO}_{2}\right)_{2}(\mathrm{tdc})_{3}\right] \cdot 4 \mathrm{H}_{2} \mathrm{O}\end{array}$ & $\sim 7$ & 2-fold 2D & 9,11 \\
\hline$\left[\mathrm{PPh}_{4}\right]_{2}\left[\left(\mathrm{UO}_{2}\right)_{2}(\mathrm{tdc})_{3}\right] \cdot 2 \mathrm{H}_{2} \mathrm{O}(7)$ & $\sim 19$ & 3-fold 2D & this work \\
\hline
\end{tabular}

${ }^{a}$ The counterions are represented in the form of the central zinc atom surrounded by the centroids of the three phen molecules.

the type of entanglement present, as well as an illustration of the entanglement. Although tdc ${ }^{2-}$ is never very far from planarity, tilting out of the uranyl equatorial plane allows some variation 
in the undulation of the sheets, clearly revealed in their width. As a matter of course, when the networks are quasi-planar, they can only be non-entangled or polycatenated in inclined 2D $\rightarrow$ 3D fashion, while slight departure from planarity allows crossing with oblique "threads" of interacting cations, and increasing curvature makes possible parallel interpenetration of increasing degree. It is at present unclear if further pursuing this trend could lead to 4-fold parallel interpenetration or, as sometimes observed with very thick networks, to parallel $2 \mathrm{D} \rightarrow$ 3D polycatenation (one example with uranyl ions having been found in a pimelate complex ${ }^{56,57}$ ), which however should probably require too strong a distorsion of the hexagonal cells. The entangled complexes in Table 3 differ by their counterions which obviously play a structure-directing role. However, no clear trend is apparent allowing to link particular characteristics of the counterion with the geometry of the network and the nature of the entanglement. For example, parallel 2D interpenetration is obtained both with a small $\left(\mathrm{Na}^{+}\right)$and a very large $\left(\mathrm{PPh}_{4}^{+}\right)$counterion, while $\left[\mathrm{M}(\mathrm{phen})_{3}\right]^{2+}$ counterions lead to a variety of geometries, not all entangled. The subtelty of the effects involved may not be surprising when considering that important topological variations arise here from small rotations of some ligands with respect to the uranyl plane, probably associated to small energetic differences.

\section{CONCLUSIONS}

In extending studies of the influence of structure-directing species upon the structure of uranyl ion complexes with 2,5-thiophenedicarboxylate, the remarkable versatility of this ligand has been further exemplified through the crystal structures of seven mono- or diperiodic coordination polymers. Except in the case of complex 1 in which the DMF cosolvent is bound to uranium and a neutral species is formed, the counterions or additional metal ions present play a prominent role in determining the periodicity, topology and possible entanglement of the complexes. The periodicity is also limited in complexes $\mathbf{2}$ and $\mathbf{3}$ due to the incorporation of 
terminal formate coligands, but all other complexes crystallize as diperiodic assemblies. Complex 4 is heterometallic, with the $\mathrm{Ni}(\text { cyclam })^{2+}$ moieties bridging uranyl-containing chains through diaxial oxo bonding, while $\mathrm{Cu}\left(R, S-\mathrm{Me}_{6} \text { cyclam }\right)^{2+}$ in $\mathbf{5}$ is separate from the sql uranyl$\operatorname{tdc}^{2-}$ network. Complexes 6 and 7 both contain diperiodic hcb subunits, these being either crossed by oblique columns of weakly interacting $\left[\mathrm{Zn}(\mathrm{phen})_{3}\right]^{2+}$ counterions in a polythreadinglike way, or 3-fold, parallel 2D interpenetrated, respectively. This and previous work show that the $\operatorname{tdc}^{2-}$ ligand has a distinct propensity to give entangled, diperiodic coordination polymers with uranyl, displaying either parallel $2 \mathrm{D}$ interpenetration of varying degree, or $2 \mathrm{D} \rightarrow 3 \mathrm{D}$ polycatenation, with the transition between the different forms being associated to varying undulation of the network. It is notable that the only triperiodic species in the uranyl-tdc ${ }^{2-}$ family results from polycatenation of diperiodic networks, the near-planarity of the ligand being adverse to the generation of frameworks, considering the peculiar geometric requirements of the uranyl cation.

\section{ASSOCIATED CONTENT}

\section{Accession Codes}

CCDC 2075811-2075817 contain the supplementary crystallographic data for this paper. These data can be obtained free of charge via www.ccdc.cam.ac.uk/data_request/cif, or by emailing data_request@ccdc.cam.ac.uk, or by contacting The Cambridge Crystallographic Data Centre, 12 Union Road, Cambridge CB2 1EZ, UK; fax: +44 1223336033.

\section{AUTHOR INFORMATION}

\section{Corresponding Authors}

*E-mail: pierre.thuery@cea.fr. (P.T.)

*E-mail: harrowfield@unistra.fr. (J.H.) 


\section{ORCID}

Pierre Thuéry: 0000-0003-1683-570X

Jack Harrowfield: 0000-0003-4005-740X

\section{Notes}

The authors declare no competing financial interest.

\section{REFERENCES}

1 Wang, K. X.; Chen, J. S. Extended Structures and Physicochemical Properties of UranylOrganic Compounds. Acc. Chem. Res. 2011, 44, 531-540.

2 Andrews, M. B.; Cahill, C. L. Uranyl Bearing Hybrid Materials: Synthesis, Speciation, and Solid-State Structures. Chem. Rev. 2013, 113, 1121-1136.

3 Loiseau, T.; Mihalcea, I.; Henry, N.; Volkringer, C. The Crystal Chemistry of Uranium Carboxylates. Coord. Chem. Rev. 2014, 266-267, 69-109.

$4 \mathrm{Su}, \mathrm{J} . ;$

5 Thuéry, P.; Harrowfield, J. Recent Advances in Structural Studies of Heterometallic UranylContaining Coordination Polymers and Polynuclear Closed Species. Dalton Trans. 2017, 46, $13660-13667$.

6 Thangavelu, S. G.; Andrews, M. B.; Pope, S. J. A.; Cahill, C. L. Synthesis, Structures, and Luminescent Properties of Uranyl Terpyridine Aromatic Carboxylate Coordination Polymers. Inorg. Chem. 2013, 52, 2060-2069. 
7 Thangavelu, S. G.; Pope, S. J. A.; Cahill, C. L. Synthetic, Structural, and Luminescence Study of Uranyl Coordination Polymers Containing Chelating Terpyridine and Trispyridyltriazine Ligands. CrystEngComm 2015, 17, 6236-6247.

8 Li, H. H.; Zeng, X. H.; Wu, H. Y.; Jie, X.; Zheng, S. T.; Chen, Z. R. Incorporating Guest Molecules into Honeycomb Structures Constructed from Uranium(VI)-Polycarboxylates: Structural Diversities and Photocatalytic Activities for the Degradation of Organic Dye. Cryst. Growth Des. 2015, 15, 10-13.

9 Thangavelu, S. G.; Butcher, R. J.; Cahill, C. L. Role of N-Donor Sterics on the Coordination Environment and Dimensionality of Uranyl Thiophenedicarboxylate Coordination Polymers. Cryst. Growth Des. 2015, 15, 3481-3492.

10 Thuéry, P.; Harrowfield, J. Counter-Ion Control of Structure in Uranyl Ion Complexes with 2,5-Thiophenedicarboxylate. CrystEngComm 2016, 18, 1550-1562.

11 Jennifer, S. J.; Jana, A. K. Influence of Pyrazine/Piperazine Based Guest Molecules in the Crystal Structures of Uranyl Thiophene Dicarboxylate Coordination Polymers: Structural Diversities and Photocatalytic Activities for the Degradation of Organic Dye. Cryst. Growth Des. 2017, 17, 5318-5329.

12 Thuéry, P.; Harrowfield, J. Uranyl-Organic Frameworks with Polycarboxylates: Unusual Effects of a Coordinating Solvent. Cryst. Growth Des. 2014, 14, 1314-1323.

13 Thuéry, P.; Harrowfield, J. Structural Consequences of 1,4-Cyclohexanedicarboxylate Cis/Trans Isomerism in Uranyl Ion Complexes: From Molecular Species to 2D and 3D Entangled Nets. Inorg. Chem. 2017, 56, 13464-13481.

14 Mei, L.; Wang, C. Z.; Zhu, L. Z.; Gao, Z. Q.; Chai, Z. F.; Gibson, J. K.; Shi, W. Q. Exploring New Assembly Modes of Uranyl Terephthalate: Templated Syntheses and Structural Regulation of a Series of Rare 2D $\rightarrow$ 3D Polycatenated Frameworks. Inorg. Chem. 2017, 56, $7694-7706$. 
15 Liu, C.; Chen, F. Y.; Tian, H. R.; Ai, J.; Yang, W.; Pan, Q. J.; Sun, Z. M. Interpenetrated Uranyl-Organic Frameworks with bor and pts Topology: Structure, Spectroscopy, and Computation. Inorg. Chem. 2017, 56, 14147-14156.

16 Hu, K. Q.; Wu, Q. Y.; Mei, L.; Zhang, X. L.; Ma, L.; Song, G.; Chen, D. Y.; Wang, Y. T.; Chai, Z. F.; Shi, W. Q. Novel Viologen Derivative Based Uranyl Coordination Polymers Featuring Photochromic Behaviors. Chem. Eur. J. 2017, 23, 18074-18083.

17 Wang, S.; Mei, L.; Yu, J. P.; Hu, K. Q.; Liu, Z. R.; Chai, Z. F.; Shi, W. Q. Large-Pore Layered Networks, Polycatenated Frameworks, and Three-Dimensional Frameworks of Uranyl Tri(biphenyl)amine/Tri(phenyl)amine Tricarboxylate: Solvent-/Ligand-Dependent Dual Regulation. Cryst. Growth Des. 2018, 18, 4347-4356.

18 Zhang, X. L.; Hu, K. Q.; Mei, L.; Zhao, Y. B.; Wang, Y. T.; Chai, Z. F.; Shi, W. Q. Semirigid Tripodal Ligand Based Uranyl Coordination Polymer Isomers Featuring 2D Honeycomb Nets. Inorg. Chem. 2018, 57, 4492-4501.

19 Zhao, R.; Mei, L.; Hu, K. Q.; Tian, M.; Chai, Z. F.; Shi, W. Q. Bimetallic Uranyl Organic Frameworks Supported by Transition-Metal-Ion-Based Metalloligand Motifs: Synthesis, Structure Diversity, and Luminescence Properties. Inorg. Chem. 2018, 57, 6084-6094.

20 Liu, C.;Wang, C.; Sun, Z. M. Conformational 2-Fold Interpenetrated Uranyl Supramolecular Isomers Based on (6,3) Sheet Topology: Structure, Luminescence, and Ion Exchange. Inorg. Chem. 2018, 57, 15370-15378.

21 Thuéry, P.; Atoini, Y.; Harrowfield, J. Structure-Directing Effects of Counterions in Uranyl Ion Complexes with Long-Chain Aliphatic $\alpha, \omega$-Dicarboxylates: 1D to Polycatenated 3D Species. Inorg. Chem. 2019, 58, 567-580.

22 An, S. W.; Mei, L.; Hu; K. Q.; Li, F. Z.; Xia, C. Q.; Chai, Z. F.; Shi, W. Q. Bipyridine-Directed Syntheses of Uranyl Compounds Containing Semirigid Dicarboxylate Linkers: Diversity and Consistency in Uranyl Speciation. Inorg. Chem. 2019, 58, 6934-6945. 
23 Thuéry, P.; Harrowfield, J. Uranyl Ion-Containing Polymeric Assemblies with cis/trans Isomers of 1,2-, 1,3-, and 1,4-Cyclohexanedicarboxylates, Including a Helical Chain and a 6Fold-Interpenetrated Framework. Cryst. Growth Des. 2020, 20, 262-273.

24 Liang, L. L.; Zhang, R. L.; Zhao, J. S. Counterion-Controlled Formation of Layered Honeycomb and Polythreading Uranyl Networks and the Highly Sensitive and Selective Detection of $\mathrm{Fe}^{3+}$ in Aqueous Media. Inorg. Chem. 2020, 59, 7980-7990.

25 Hou, X.; Tang, S. F. Variability of Uranyl Carboxylates from Rigid Terophenyldicarboxylic Acid Ligands. Inorg. Chem. 2020, 59, 15824-15831.

26 Pang, Z. H.; Luo, F. A Highly Rare 3D U-Cu Metal-Organic Framework Showing ThreeConnected srs Topology and Nine-Fold Interpenetration. Inorg. Chem. Commun. 2020, 119, 108041.

27 Thuéry, P.; Harrowfield, J. $[\mathrm{Ni}(\text { cyclam })]^{2+}$ and $\left[\mathrm{Ni}\left(R, S-\mathrm{Me}_{6} \text { cyclam }\right)\right]^{2+}$ as Linkers or Counterions In Uranyl-Organic Species with cis- and trans-1,2-Cyclohexanedicarboxylate Ligands. Cryst. Growth Des. 2018, 18, 5512-5520.

28 APEX3 Crystallography Software Suite, ver. 2019.1-0; Bruker AXS: Madison, WI, 2019.

29 SAINT, ver. 8.40A; Bruker Nano: Madison, WI, 2019.

30 SADABS, Bruker/Siemens Area Detector Absorption and Other Corrections, ver. 2016/2; Bruker AXS: Madison, WI, 2016.

31 Krause, L.; Herbst-Irmer, R.; Sheldrick, G. M.; Stalke, D. Comparison of Silver and Molybdenum Microfocus X-Ray Sources for Single-Crystal Structure Determination. J. Appl. Crystallogr. 2015, 48, 3-10.

32 Sheldrick, G. M. SHELXT - Integrated Space-Group and Crystal-Structure Determination. Acta Crystallogr., Sect. A 2015, 71, 3-8.

33 Sheldrick, G. M. Crystal Structure Refinement with SHELXL. Acta Crystallogr., Sect. C 2015, $71,3-8$. 
34 Hübschle, C. B.; Sheldrick, G. M.; Dittrich, B. ShelXle: a Qt Graphical User Interface for SHELXL. J. Appl. Crystallogr. 2011, 44, 1281-1284.

35 Spek, A. L. PLATON SQUEEZE: a Tool for the Calculation of the Disordered Solvent Contribution to the Calculated Structure Factors. Acta Crystallogr., Sect. C 2015, 71, 9-18.

36 Farrugia, L. J. WinGX and ORTEP for Windows: an Update. J. Appl. Crystallogr. 2012, 45, 849-854.

37 Momma, K.; Izumi, F. VESTA 3 for Three-Dimensional Visualization of Crystal, Volumetric and Morphology Data. J. Appl. Crystallogr. 2011, 44, 1272-1276.

38 Blatov V. A.; Shevchenko, A. P.; Proserpio, D. M. Applied Topological Analysis of Crystal Structures with the Program Package ToposPro. Cryst. Growth Des. 2014, 14, 3576-3586.

39 Dance, I.; Scudder, M. Supramolecular Motifs: Concerted Multiple Phenyl Embraces between $\mathrm{Ph}_{4} \mathrm{P}^{+}$Cations are Attractive and Ubiquitous. Chem. Eur. J. 1996, 2, 481-486.

40 Spackman, M. A.; Jayatilaka, D. Hirshfeld Surface Analysis. CrystEngComm 2009, 11, 1932.

41 Wolff, S. K.; Grimwood, D. J.; McKinnon, J. J.; Turner, M. J.; Jayatilaka, D.; Spackman, M. A. CrystalExplorer, University of Western Australia, 2012.

42 Taylor, R.; Kennard, O. Crystallographic Evidence for the Existence of C-H $\cdots \mathrm{O}, \mathrm{C}-\mathrm{H} \cdots \mathrm{N}$, and C-H...Cl Hydrogen Bonds. J. Am. Chem. Soc. 1982, 104, 5063-5070.

43 Desiraju, G. R. The C-H‥O Hydrogen Bond: Structural Implications and Supramolecular Design. Acc. Chem. Res. 1996, 29, 441-449.

44 Spek, A. L. Structure Validation in Chemical Crystallography. Acta Crystallogr., Sect. D 2009, $65,148-155$.

45 Zhang, Y.; Chen, L.; Guan, J.; Wang, X.; Wang, S.; Diwu, J. A Unique Uranyl Framework Containing Uranyl Pentamers as Secondary Building Units: Synthesis, Structure, and Spectroscopic Properties. Dalton Trans. 2020, 49, 3676-3679. 
46 Thuéry, P.; Atoini, Y.; Harrowfield, J. Isomerism in Benzenetricarboxylates: Variations in the Formation of Coordination Polymers with Uranyl Ion. Cryst. Growth Des. 2020, 20, 7368 7383.

47 Etter, M. C.; MacDonald, J. C.; Bernstein, J. Graph-Set Analysis of Hydrogen-Bond Patterns in Organic Crystals. Acta Crystallogr., Sect. B 1990, 46, 256-262.

48 Bernstein, J.; Davis, R. E.; Shimoni, L.; Chang, N. L. Patterns in Hydrogen Bonding: Functionality and Graph Set Analysis in Crystals. Angew. Chem. Int. Ed. 1995, 34, 1555-1573.

49 Thuéry, P.; Atoini, Y.; Kusumoto, S.; Hayami, S.; Kim, Y.; Harrowfield, J. Optimizing Photoluminescence Quantum Yields in Uranyl Dicarboxylate Complexes: Further Investigations of 2,5-, 2,6- and 3,5-Pyridinedicarboxylates and 2,3-Pyrazinedicarboxylate. Eur. J. Inorg. Chem. 2020, 4391-4400.

50 Jiang, J.; Sarsfield, M. J.; Renshaw, J. C.; Livens, F. R.; Collison, D.; Charnock, J. M.; Helliwell, M.; Eccles, H. Synthesis and Characterization of Uranyl Compounds with Iminodiacetate and Oxydiacetate Displaying Variable Denticity. Inorg. Chem. 2002, 41, 27992806.

51 Thuéry, P.; Harrowfield, J. Tetrahydrofurantetracarboxylic Acid: an Isomerizable FrameworkForming Ligand in Homo- and Heterometallic Complexes with $\mathrm{UO}_{2}{ }^{2+}, \mathrm{Ag}^{+}$and $\mathrm{Pb}^{2+}$. Cryst. Growth Des. 2016, 16, 7083-7093.

52 Thuéry, P.; Atoini, Y.; Harrowfield, J. Functionalized Aromatic Dicarboxylate Ligands in Uranyl-Organic Assemblies: The Cases of Carboxycinnamate and 1,2-/1,3Phenylenedioxydiacetate. Inorg. Chem. 2020, 59, 2923-2936.

53 Unruh, D. K.; Libo, A.; Streicher, L.; Forbes, T. Z. Synthesis and Characterisation of 1-D Uranyl Thiodiglycolate Coordination Polymers. Polyhedron 2014,73, 110-117. 
54 Thuéry, P.; Atoini, Y.; Harrowfield, J. 1,3-Adamantanedicarboxylate and 1,3Adamantanediacetate as Uranyl Ion Linkers: Effect of Counterions, Solvents and Differences in Flexibility. Eur. J. Inorg. Chem. 2019, 4440-4449.

55 Thuéry, P.; Atoini, Y.; Harrowfield, J. Chiral Discrete and Polymeric Uranyl Ion Complexes with $(1 R, 3 S)-(+)$-Camphorate Ligands: Counterion-Dependent Formation of a Hexanuclear Cage. Inorg. Chem. 2019, 58, 870-880.

56 Thuéry, P.; Harrowfield, J. Counterion-Induced Variations in the Dimensionality and Topology of Uranyl Pimelate Complexes. Cryst. Growth Des. 2016, 16, 2826-2835.

57 Chakraborty, G.; Park, I. H.; Medishetty, R.; Vittal, J. J. Two-Dimensional Metal-Organic Framework Materials: Synthesis, Structures, Properties and Applications. Chem. Rev. 2021, $121,3751-3891$. 


\section{2,5-Thiophenedicarboxylate: an Interpenetration-Inducing Ligand in Uranyl Chemistry}

Pierre Thuéry and Jack Harrowfield

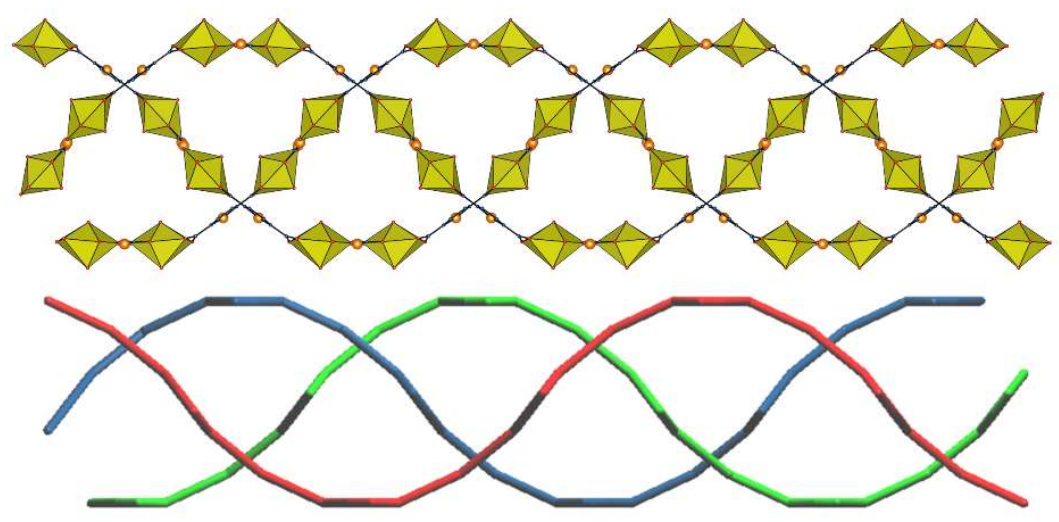

Depending on the structure-directing species present, uranyl cations associate with 2,5thiophenedicarboxylate ligands to form mono- or diperiodic coordination polymers of varying geometry. In particular, honeycomb networks are found either associated with columns of counterions in polythreading-like fashion, or 3-fold interpenetrated, an entanglement mode not previously known in this family. 